\title{
The Essence of Semiotic Theory in Athol Fugard's Four elected Plays
}

\author{
Margaret Njoki Mwihia
}

Mount Kenya University, School of Social Sciences

Email: njokimwihia@yahoo.com

\section{Doi:10.5901/mjss.2015.v6n2s1p268}

\begin{abstract}
In the analysis of literary works, critics make use of various theories depending on what their interest is for the particular work. This paper is grounded in semiotics literary theory. Semiotics, translated as the science of signification, is often said to derive from two sources: F. de Saussure (Swiss-French, 1857-1913) and C.S. Peirce (Anglo-American, 1839-1914). Some other researchers known for their work in semiotics are Noam Chomsky, Umberto Eco, R. Barthes and Jean Baudrillard.
\end{abstract}

Keywords: Semiotic, Theory, Play, Style, Writing, Translation

\section{Background}

Semiotics is the theory of the production and interpretation of meaning. Its basic principle is that meaning is made by the deployment of acts and objects which function as "signs" in relation to other signs. Systems of signs are constituted by the complex meaning-relations that can exist between one sign and another, primarily relations of contrast and superordination/subordination (e.g. class/member, whole/part). Signs are deployed in space and time to produce "texts", whose meanings are construed by the mutually contextualizing relations among their signs. The mutually contextualizing relations in Athol Fugard's drama have to do with his style of character development and characterization as a style. There are two major traditions in European semiotics: F. de Saussure, semiology; and C.S. Peirce, semiotics. Saussure's approach was a generalization of formal, structuralist linguistics; Peirce's was an extension of reasoning and logic in the natural sciences.

General Semiotics tends to be formalistic, abstracting signs from the contexts of use; Social Semiotics takes the meaning-making process, "semiosis", to be more fundamental than the system of meaning-relations among signs, which are considered only the resources to be deployed in making meaning.

Multimedia semiotics is based on the principle that all meaning-making, because it is a material process as well as a semiotic practice, necessarily overflows the analytical boundaries between distinct, idealized semiotic resource systems such as language, gesture, depiction, action, etc. Every material act and sign can be, and usually is, construed in relation to more than one system of sign relations (e.g. a written word is both a linguistic sign and a visual orthographic one; a spoken word is also construed in relation to its non-linguistic acoustical qualities; an image is interpreted both visually and usually also linguistically; etc.). Therefore it becomes important to study how different sign-systems are physically and semiotically integrated in texts and multimedia productions of various kinds.

Social semiotics examines semiotic practices, specific to a culture and community, for the making of various kinds of texts and meanings in various situational contexts and contexts of culturally meaningful activity ( Eco 1976).

In the analysis of Athol Fugard's work, semiotic literary theory is employed since our assumption is that the playwright uses the characters as signifiers and what they signify has to do with the playwright's concerns and artistic vision. From the analysis of the selected texts it is clear that Athol Fugard uses the technique of characterization and the symbolic representation of different situations to artistically communicate his vision of a better South Africa. He focuses on the real, which is the situation of the apartheid system to point out what he views to be the ideal.

In Hello and Goodbye both the father and mother of the two siblings Hester and Johnnie are absent. However they are important in determining the story line and the playwright's vision. Their absenteeism forms ground for the antagonism of their children. The mother is dead and that makes the home unbearably lonely. Hester decides to leave the home only to come back after twelve years to demand her part of inheritance.

The money Esther was demanding was supposedly paid as their father's compensation for his leg which he had lost in an accident. The father's lost leg is symbolic of stagnation. He can't move well with one leg and hence the stagnation which affects everyone around him. In the case of Johnnie's father, he becomes a load to his son Johnnie who 
has to be at home all the time to take care of him. The whites are a load to the blacks and they have to be served all the time.

Johnnie does not get a chance to be trained in any skill and when his father dies he is tempted to inherit the clutches so that he can go to the streets and live on begging. Hester is the one who comes out with Fugard's vision here by discouraging her brother from disguising as a cripple. She tells him that he should try and get himself any job. Fugard's vision is that the blacks should be themselves and not aspire to be like the whites at all. His vision for the people in South Africa is that they would succeed in being themselves and there is nothing worthy in any race aping the other people.

Johnnie tells his sister that in his anger, their father has been talking of her as having her mother's English blood and not his Afrikaner blood. This is because of the scramble for resources the two siblings. Hester and Johnnie are alienated to each other. The blacks and whites in South Africa are alienated to each other because of the scramble for resources. Hester is selfish and she wants her father's money but she will not serve him. Johnnie serves their father to the end and yet when Hester arrives she wants everything in form of money claiming that she is a daughter and hence deserves to be given her share. The father is a cripple and is ailing. There is nothing to be inherited by the children. There are only the clutches. Johnnie says he will keep the clutches and go to the streets to beg. His sister discourages him but she has nothing to offer. These absent, crippled and ailing fathers are a burden to other people. They have nothing to offer. Their presence shows the crippling effects of the apartheid regime in South Africa.

In Master Harlod and the Boys, we also encounter absent parents. The mother is busy nursing a crippled and ailing father. This man is a bother to his wife and child Hally. The problems spill over to the servants who have to carry him home when he is drunk. It is bad enough to serve a cripple but it is worse when the same is drunk. Drunkardness adds up more problems because in the play it is said he shits in his pants. The servants have to carry him with the shit as his small son Hally follows.

Fugard is satirizing Hally's father to show the magnitude of problems brought about by the apartheid regime. The whites are a real bother to the blacks. Because of the white Skin, Hally's father has no respect for his black servants. Hally tells Sam that his father's advice is that he keeps distance from the black servants. The mother also beats him when she discovers that she has been playing around with the black servants. The whites want nothing to do with the blacks but they make use of them to do difficult tasks like Sam carrying the crippled man on his back.

In Blood knot, Zachariah's real mother and a fake mother, his girlfriends like Connie and Minnie, and Ethel his pen pal are all invisible but they not only shape the story line but they have a great impact on the story itself. In making use of these absent characters, Fugard is showing the invisible but always present power of the regime.

In Blood Knot, the real mother of the two characters is absent because she is supposedly dead. She is however symbolic of South Africa. She had two children. One is black and the other one is white. That tells us that South Africa belongs to two races; the blacks symbolized by Zachariah and the whites symbolized by Morris. The fake mother symbolizes apartheid and when chased away by one son she becomes stubborn. She only disappears when the two sons join hands and chase her away. This signifies that fighting apartheid has to take the effort of both the blacks and the whites.

Ethel is a pen-pal and she is symbolic of apartheid. Morris tries to make his brother Zachariah take a pen pal to replace his desire for a woman. It can't work. Apartheid cannot replace the real freedom the blacks need. Minnie and Connie are real. Zachariah remembers with nostalgia the enjoyment he had when Minnie visited him and they went out together. He felt satisfied that he had a real woman. The blacks need real freedom not the imaginary independence in form of apartheid where they suffer in their own country. It has also been established that Fugard's women characters never appear on stage. Their influence however is felt although they are invisible characters through the visible ones.

Heroes suffer as Athol Fugard also suffered at a certain times. His passport was withdrawn due to writing and acting The Blood Knot a play that highly attacks the vices of apartheid. The essence of this research study is established as Fugard's social vision for his people. It is a kind of messianic hope that the vision comes out through the characters who are carrying the writer's voice. These are the people who turn situations around and change things so that the oppressed gets out of his position sometimes through violence or through dialogue. The blacks in South Africa have been historically oppressed and the playwright gives his 'savior' characters the roles of saviors in the four plays. In each play these characters carry the playwright's voice.Commenting on the relevance of literature to the society, Mongane (1989) says:

Literature is part of the structure of the society, it may simply record the kind of society the writer knows-its values, problems, structure, events, etc. or it may attack this very society and its present evils. Literature more often embodies the writer's evaluation of his world or illuminates its possibilities. (115) 
The playwright attacks the evils of Apartheid through the voices of the characters.

Fugard uses the two characters John and Winston in The Island to show the vision he has throughout the play. At first Winston doesn't identify with his position. He is in such great pain that he wants no more trouble from the 'Hodoshe' the warden. He also feels that the part John is giving him will make him a laughing stock by the other inmates because 'Antigone' is a girl prompting him to wear womanly. However when he agrees to take the part in the play Antigone the character 'Antigone' the brave girl opens him up and he is the one that comes out with the social vision as he takes the part of 'Antigone' ploynice's sister who bravely states that she buried the body of her brother because it was right. Asked whether she knew the consequences of the law she broke she said yes and fearlessly pleaded guilty.

Winston realizes then that he is equivalent to 'Antigone' in terms of his position in society. He is regarded as a lesser being in South Africa and the authorities' intention is to break him in the dehumanization in the futile and cruel mistreatment in jail. 'Antigone' is punished for burying the dead body of a brother who according to the authorities should be left to rot in the battle field because he was against the politics of that day.

Athol Fugard by making John take the part of Creon the king in Sophocle's text Antigone states:

John: Two bothers of the House of Labdacus found themselves on opposite sides in battle,the one defending the state, the other attacking it. They both died in the battle field. The Head of state King Creon decided that the one who had defended the state should be buried with all religious rites due to the noble dead.But the other one, the traitor Polynices who had come back from exile intending to burn and destroy his fatherland; to drink the blood of his masters, was to have no grave, no mourning. He was to lie on the open fields to rot or at most be food for the jackals.It was a law.(73)

This shows the magnitude of inhumanity that Sophocles was addressing in his text and Fugard uses it to also address the inhumanity accorded to the south african blacks in South Africa.From the fact that Fugard wo:rks with the black friends John Kani who takes the part of John and Winston Ntishona who takes the part of Wiston in the play, he as the playwright is taking too brave a stand considering the situation of the apartheid politics in South Africa at that time. This play, The Island which was first performed on July the second 1973,shows that Fugard was crossing the colour bar lines. Like Sophocles the playwright of the play Antigone Fugard is doing so because it only right and human. His Vision is that at one time in South Africa, people will act not according to laws of apartheid made by man but according to humane laws. Fugard(1976) in the play within a play style has Winston taking the part of Antigone Sophocle's character who states that "even as there are laws made by man, there are also laws made by God"(76). Fugard using this Biblical allusion stresses the need of love for human kind regardless of colour.

Antigone's argument is that when Polynices died in battle he was just a dead body which needed a burial like any other. It doesn't matter which side he was fighting in. His brother Eteodes died in the same battle and was accorded a heroic burial. It is just the same thing that the sister was doing to Polynices. She buried a body that could neither help nor hurt anybody. This was human. Fugard's vision is that in South Africa people will look at each other as human beings. It does not matter what colour one is as long as one is a human being.Antigone states that she doesn't fear the sentence because her conscience is clear.

Guilty against God I will not be for any man on this earth. Even without your law Creon, and the threat of death to whoever defied it, I know I must die. Because of your law and my defiance, that fate is now very near... Your threat is nothing to me Creon. But if I had left my mother's son a son of the land lie there as food for the carrion fly, Hodoshe, My soul would never have known peace. (76)

Fugard's social vision is that the people of South Africa will arrive at a decision to defend each other's right like the way Antigone does without fear. The blacks are humans and they need social protection like Polynices needed a decent burial. The whites should realize that the blacks are human beings. Those few whites like the writer who associate with blacks and work with them should be supported. Antigone is playing the role of one who selflessly gives up his life to stand for what is true and just.

She bravely faces the king after his long speech and the dialogue continues:

John: You are accused that,in defiance of the law,you buried the body of the traitor Polynices.

Winton: I buried the body of my brother Polynices.

John:Did you know there was a law forbidding that?

Winston: Yes.

John: Yet you defied it.

Winston:Yes.

John: What did you plead to the charges laid against you? Guilty or not guilty?

Winston:Guilty. 
That conversation from the original Antigone is evidence of the fact that she was ready to die for what is true and right. She defies the law of man because it is unfair to her underprivileged brother whose body though harmless is doomed to be left to rot in the battlefield like that of an animal. Antigone buries him against that man-made law. The playwright is showing that there are laws made by men that are sometimes against humanity and calls the audience to criticize them as the character Winston posing as Sophocles' Antigone does.

It is clear that the State as represented by Creon is unfair in condemning Antigone but it is the law that governs the state that defends the powerful against the weak and his is comparable to the powerful white man in South Africa oppressing the weak black man with the apartheid laws that Athol Fugard loathes as evidenced by the use of Sophocles' Antigone. Antigone is not cowed by Creon when he tells her that she has pleaded guilty and should therefore say something in mitigation.

She challenges him to explain the severity of the unfair law in the conversation below:

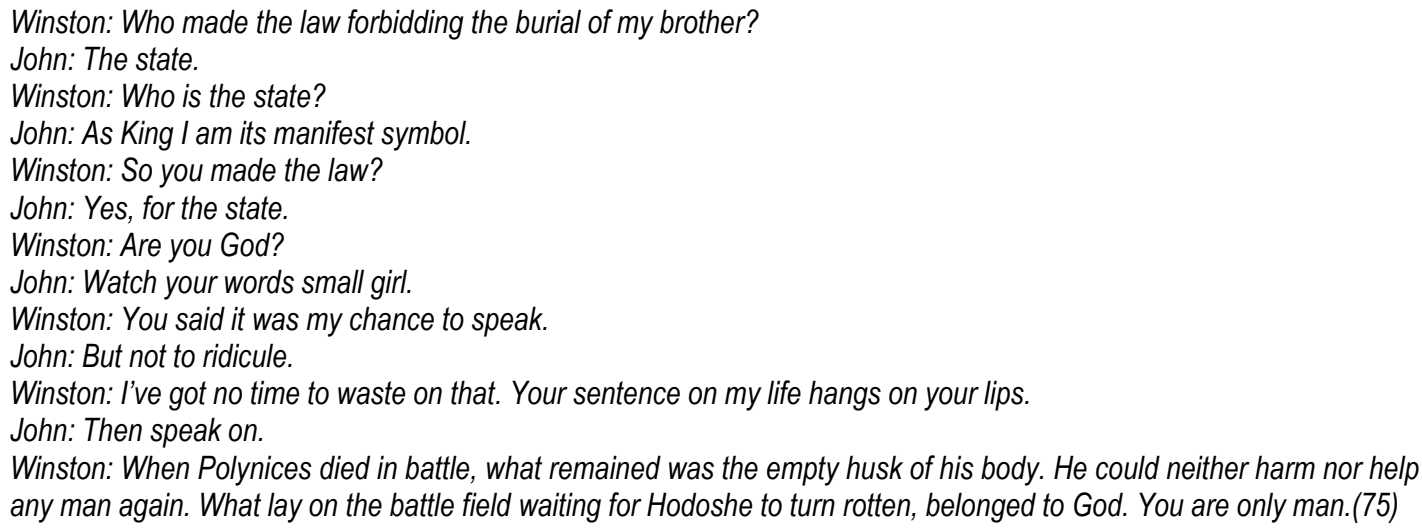

From the conversation above, the audience is left with no other choice but to admire the way Antigone takes Creon to task by making him show how unfair the law he stands for deals with the same people they are supposed to defend. This is part of Fugard's vision that the people of South Africa may have their eyes open to the reality of apartheid and its dehumanizing laws.

When Antigone asks Creon whether he is God, she is trying to challenge him to see the unfairness of the law he stands for so that he may see the other side of the oppressed. The playwright makes the two brothers die in the same battlefield to show that there is no difference between them in terms of the fate for all humankind. They all die whether they are on the side of power or not. Given the choice to save, Creon would have saved Eteocles because he was said to be fighting for the state and would have killed Polynices who was termed as an enemy of the state and a traitor. However, nobody has power over life and death but God. Antigone states:

\begin{abstract}
Even as there are laws made by men, so too there are others that come from God. He watches my soul for a transgression even as you spies hide in the bush at night to see who is transgressing your laws. Guilty against God I will not be for any man on this earth. Even without your law I must die. Because of your law and my defiance, that fate to me is very near...Do you nderstand anything of what I am saying Creon?(75)
\end{abstract}

From these words said by an ordinary girl to a king it is clear that she is fearless and has courage to stand for what is true and just though alone.

Wertheim,(2000 )posits that:

The island is not merely Robben island but South Africa itself, an absurd prison with absurd rules where enforced by absurd rules enforced by absurd officials. South Africa's citizens be they non-white or whites, are as much immured and imprisoned as either the heroine in Sophocle's play or the prisoners in Fugard's.(98)

In those words Wertheim is stating how apartheid system imprisons even the white man as well as the black despite the fact that the former is the author of the same system that entangles him making him an equal prisoner. In agreement with those words the study establishes that in South Africa even the whites are imprisoned by the fact that they mistreat the blacks because the system dictates so. Antigone like all historical and religious heroes looks for truth and pays with her life as she is condemned to death with the following words from Creon: "There was a law. The law was broken. The law stipulated its penalty. My hands are tied. Take her from where she stands, straight to the island! There 
wall her up in a cell for life, with enough food to acquit ourselves of the taint of her blood" (76). Those words allude to guilt. When one commits evil, he still feels guilty no matter how one tries to exonerate himself. No doubt Creon knows that his sentence to an innocent girl is unjust but there is a law as he states that whoever goes against the state should be punished.

Sophocle's character makes the audience realize that the law and the law makers are unfair. Antigone succeeds in doing so as shown in her words that she finally goes to her living death because of doing the right thing .Fugard uses an ironical statement 'living death' to emphasise the kind of life Antigone will go through. Life in prison as we learnt at the beginning of the play is unbearably difficult and soul breaking. This is comparable to the life the citizens of South Africa go through whether they are black or white. The blacks are mistreated like evidenced from the two prisoners John and Winston.

The warden Hodoshe is not spared either. Even if he doesn't suffer physically, he suffers psychologically in having to execute pain on the prisoners and watching them suffer. He suffers alienation and is left alone as the prisoners go back to their lonely cells painfully. Through Hodoshe, the playwright is showing the whites that there is nothing profitable in doing evil against their black brothers and if anything it also costs them their pleasure. As Hodoshe watches the inmates suffering, he cannot enjoy as a human being otherwise he would be sacrificing his humanity.

At the end of the play, Winston tears off his wig and confronts his audience as Winston and not Antigone. All through, Winston was taking another person's place and now when he tears off the wig, reality dawns on the other prisoners that all the evil done against Antigone is done against Winston their comrade and so it is also on them. The other inmates are able to identify with Winston because they know him unlike Antigone who looks a legendary heroine. Earlier in the play as the two inmates were preparing to act Antigone, Winston had explained it away as child play.

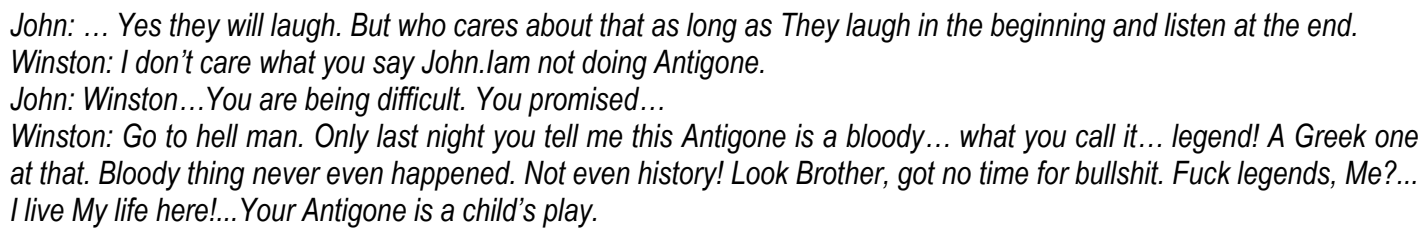

Later on he realized himself as a victim of the same law and decides to act. Although Polynices was against the law of the state his dead body should be laid to rest in whichever manner. The state ceremony can be eft out because he was fighting against the state for whatever reasons he had. It was unfair for Creon to have people spying on whoever would try to bury the dead body. Winston had considered Antigone's role as belittling him because Antigone was a woman. Later he realized that he himself is belittled by the apartheid regime because he is a black. Towards the end he identifies with Antigone regardless of her being a Greek creation. This is because she is a human being who has been misjudged despite her colour. A wrong committed to a human being is a wrong regardless of whom it is committed to. Their conversation is interrupted by Hodoshe who calls John from outside their cell and they are afraid as usual because Hodoshe's call means bad news for them. Fugard makes use of Winston as the messianic character in this play.He carries the vision of the playwright in that he opens the eyes of the audience through Antigone's bravery.

Antigone is so brave that even as she listens to Creon's verdict she shows no fear because she believes she did the right thing. The message here is that honour belongs to all mankind and should be given without bias and it is Creon who goes against humanity and not Antigone. Antigone thus carries the messianic hope in Antigone. Winston acting Antigone's part is taking the messianic role in the play.

The playwright explains his social vision though three characters Sam, Hally and Willie in Master Harold and the Boys. At the beginning of the play, the place we are introduced to shows simplicity and poverty. There are some simple utensils that can only mean a simple meal for a simple person. Even the food is simple. There are a few stable cakes, sweets and cool drinks. There is a blackboard on which an untrained hand has written the prices of simple food like tea, coffee, scones and milkshakes. There is also a telephone and an old-style jukebox. This setting is a simple hotel with an entrance and exit. The cast is composed of three characters. One is a black man in his mid-forties wearing a white coat. $\mathrm{He}$ is the waiter in the simple hotel. He sits on a solitary table reading a comic book. His name is Sam. The other one is another black man of the same age with his sleeves and trousers rolled is in a kneeling position. His name is Willie. With the two characters we are introduced to poverty. The third character is a youth. He is a white boy. When he is introduced in the play, he is coming from school. The rain is falling and he is wearing a rain coat. His hair is wet and Sam brings him a towel to dry it.

Immediately we are made aware of the supremacy of white skin. The whites are served by the blacks despite their age. This new character is a young boy of seventeen. When he enters, the stage all the activities by the other two come 
to a halt. They begin to attend him. His name is Hally short for Harold. The two black men call him Master. So he is referred to as Master Hally.

This supremacy of colour is what the character Morris in Blood Knot referred to as 'whiteness' and that it goes with power. The whiteness means superiority. The two black men are in their mid-forties. They are adults but they are referred to as boys. The title "Master Harold and the Boys" tells is symbolic of that. The blacks are belittled even though they are adults old enough to father Hally. Their skin gives them their position. Fugard gives his black characters a bigger age but inferior positions socially. This is meant to show the audience that in South Africa there is not only color stratification but also social segregation. One is what he is socially because of his colour.

Hally is then given food and briefed of the happenings of the day. His father is at the hospital and his mother has gone to visit him there. The father is a cripple physically but because of his skin colour, he has power to make the black servants carry him on their backs when he is drunk and filthy. He shits on his trousers and expects to be dragged home by black servants. He is stinking of beer and shit and yet he orders his servants around because they are disadvantaged by their blackness.

\section{Conclusion}

South Africa needs a complete change like a resurrection. Before a resurrection, there must be a death. Apartheid must die so that South Africa can be resurrected. This is Fugard's vision for South Africa in this play. When apartheid dies, then newness will come.In all the four plays, Fugard has shown that change is invertible. The good news is that Fugard's social vision has already been fulfilled in history. The resurrection came about with the release and consequently the new rule by the first black president Nelson Mandela fulfils Fugard's social vision. The blacks and whites should learn to live with each other like the characters in the four plays. It is the hope of this study that other researchers can do more on other plays by the same author especially those written after the demise of the apartheid regime to establish whether his social vision has been accomplished in the new era.

\section{References}

Adedoja, E.(2010). Social relevance of African literature to the promotion of social values. Kwara State Polytechnic Ilorin October 2010, Volume 7, No.10 (Serial No.82), 2010.

Alan, F.(1970). The Turn of the Novel: The Transition to Modern Fiction. London: O.U.P.

Alan, P.(1948). Cry the Beloved Country. New York: Scribner.

Albert B. L.(1975). The Singer of Tales. N.Y.: Atheneum.

Albert, W.(2000) .The Dramatic Art of Athol Fugard. UK: Indiana University Press.

Alex, I. (1964). What Is Sociology? London: Prentice Hall.

Barthes, R. (1967). Elements of Semiology (trans. Annette Lavers \& Colin Smith). London: Jonathan Cape.

Baudrillard, J. \& Poster, M. (1988). Selected Writings. Cambridge: Polity Press.

Best, S. (2003). A Beginner's Guide to Social Theory. London: Sage Publications.

Blessler,C. (2007). Literary Criticism: An introduction to Theory Practice. $4^{\text {th }}$ Ed. Upper Saddle River: Pearson Education, Inc. Bolagun, P. O. (2003). Archetypes in African Literary Oral Literary Traditions: an Exampl J. P. Clark's

Brinkerhoff, D., Lynn, K. and Suzanne T. Ortega. (2005) Essentials of Sociology. USA. Wadsworth Publishing Company.

Brutus,S. (1969). The Writers in Modern Africa. 3rd Ed. New York:Africana Publishing Corp. Caesar, J. (1973). Drama. U.S.A: Scholastic Magazines Inc.

Carrigan, R. (1970). Theatre in the $20^{\text {th }}$ Century. New York: Tulane.

Cass, J. (1967). Literature and Young Children. London: Oxford University Press.

Cassady,and Pat.(1975). Theater and Drama. USA: NTC Publishing Group.

Chatman, S. (1981). Literary Style. London: Oxford University Press.

Dennis, D. and Cosmos Pieterse (1972). African WritersTalking. London: Heinemann Educational Books Ltd.

Dennis, E. and Cosmos Pieterse.(1972). African Writers Talking. London: Heinneman Educational Books Ltd.

Dennis, W. (2003). Athol Fugard: Writers and Their Work. Britain:North Cote.

Durosimi, E. and Marjorie Jones. (1996). New Trends and Generations inAfrican Literature. North Cote. London: James Currey.

Eco, U. (1976). A Theory of Semiotics. Bloomington, IN: Indiana University Press.

Edgar, R. (1999). Writing about Literature: Brief 9th Ed. New Jersey: Prentice Hall.

Elegba, A.(2010). Social Relevance of African Literature to the Promotion of Social Values. Ilorin;Kwara State Polytechnic.

Erapu, L. (1977). John Ruganda's The Burdens. Nairobi: Heinemann Educational Books.

February, V. (1981). Mind Your Colour. London: Kegan Paul InternationalLtd.

Fonagy, P.and Bateman. (2008).Psychoanalytic Constructs. New York: Guilford Press.

Fonagy,P. and Bateman. (2006). Mechanism of Change in Mentalization based Treatment. United Kingdom: JohnWiley. 
Fonagy,P. and Target.(2003). Psychoanalytic Theories. New York: Whurr Publications

FonagyP. and Bateman.(2004).Psychotherapy for Borderline Personality. New York: Oxford University Press.

Friedman,A.(1970). The Transition of Modern Fiction. London: Oxford University Press.

Fugard, A. (1987). Blood Knot. New York: Oxford Universitity press.

Fugard, A. (1976). The Island. New York: Vikings Press.

Fugard, A. (1984). Master Harold and the Boys. New York: Penguins.

Fugard, A. (1974). Hello and Goodbye. New York: Oxford University Press.

Gachukia E. (1978). Teaching of African Literature in Schools. Nairobi: East African Educational Publishers.

Gergen,K and Mary Gergen. Social Psychology. New York: Hacourt Brace Jovanovich.

Gikandi, S. (1987). Reading the African Novel. London: James Currey.

Goldthorpe, J. (1982). An Introduction to Sociology. London: Cambridge University Press

Gray, S. (1982). Athol Fugard. Johannesburg: Mc Graw-Hill.

Griffith, K. (2006). Writing Essays About Literature: A guide and Style Sheet $7^{\text {th }}$ Ed.USA: Michael Rosenberg.

Guerin, W. etal. (1999). A Handbook of Critical Approaches to Literature. New York: Oxford University Press.

Hacker, D. (1969). Rules for Writers 3rd Ed. NewYork: Bedford Books of St. Martins Press.

Hatch, J. and Ted Shine. (1996). Black Theatre. U.SA: Macmillan Publishers.

Head, D. (1994). Nadine Gordimer. Great Britain: CambridgeUniversity Press.

Hill, E. (1981). The Theatre of Black Americans. Vol. 11. Jersey: Prentice Hall.

Hofer, M.(1981).The Roots Of Human Behaviour. USA:W.H.Freeman\&Company.

Inkels, A. (1964). What is Sociology? London: Prentice Hall Inc.

Kabiru, M. and Anne Njenga.(2009). General Psychology and Personality Development. Nairobi:Acme Press.

Leech, G. and Mick Short. (1981). Style and Fiction. London: Longman.

Lord, A.B.(1975). The Singer of Tales.New York:Atheneum.

Lucas, F. (1955). Style. Great Britain: Cassel and Co. Ltd.

Lyons, J. (1981). Language and Linguistics. Great Britain: Cambridge University Press.

Maag, J. (2004). Behavioral Management. Canada: WadsworthMcgowan.

Mahoni ,J. Frank ,B. and Tony Romano. Psychology and You. USA: West Publishing Co.

Mott ,E. P. (1965). The Organisation of Society. USA: Prentice Hall Inc.

Mphalele, E. (1972). Voices in The Whirlwind and Other Essays. New York: Hill and Young.

Ngara, E. (1982). Art and Ideology in the African Novel. Nairobi: Heinemann.

Nkosi, L. (1983) Tasks and Masks. Nairobi: Heinmann

Norton,P.and Joseph Esposito.(1994). TheNewEncyclopediaBritannica.vol28. Chicago :Encyclopedia, Britannica Inc.

Nuebeck, K.,Mary Nuebeck and Davita Glasberg.(1979) Social Problems. New York: Mc Graw Hill Co.

Parker, K. (1978). The South African Novel in English. New York: Macmillan.

Paton, A. (1948). Cry the Beloved Country. New York: Scribner.

Peck, J. and Martin Coyle. (1993). Literary terms and Criticism New Ed. London: Macmillan.

Peirce, C. S. (1931-58). Collected Writings (8 Vols.). (Ed. Charles Hartshorne, Paul Weiss \& Arthur W Burks). Cambridge, MA: Harvard University Press.

Peters, J.M. (1987). In het teken van het beeld. Beknopte introductie tot de semiologie. In J. Bardoel \& J. Bierhoff (Eds.), Informatie in Nederland, theorie, achtergronden. Groningen: Wolters-Noordhoff

Ramage, J., John Ben and June Johnson. (1996). The Allyn and Bacon Guide to Writing. New York: Bedford books of St. Martin's Press.

Robert, C. (1970). Theatre in the Twentieth Century. New York. Tulane Drama Review.

Robert, H. Lauler.(2005). Social Problems and the Quality of Life. USA: Mc Graw Hill Co.

Robert, R.K. (2005). Psychology. USA: John Willey \& Son Inc.

Rose ,I.. P., Peninah M. Glazer and Myron Peretz Grazer. (1990). Sociology. USA. Prentice Hall.Inc.

Ruby, C. (1969). Currents in Contemporary Drama. London: Indiana University Press.

Ruganda, J. (1992). Telling the Truth Laughingly. Nairobi. East African Educational Publishers.

Saussure, F. de (1983). Course in General Linguistics (trans. Roy Harper)

Scarlyn, N. (1937). European Drama. Great Britain: C. Tringlin \& Co.

Short, M. (1989). A dictionary of Stylistics. London: Longman.

Styan, J. (1993). Modern Drama in Theory and Practice 3. New York: Britain: Jonathan Cape.

Styan, J. (1993). The Elements of Drama. New York: Cambridge University Press.

Thompson, J. (1982). Sociology. England: Clay Ltd.

Tyson L. (2005). Critical Theory Today. New York: Rout ledge.

Wa Thiong'o, N. (1991). Moving the Centre. Nairobi: Heinemann Educational Books.

Wanjala, C. (1973). Standpoint on African Literature. Nairobi East African Literature Bureau.

Wellek,R.andAustinWarren.(2000). TheoryofLiterature.Britain:JonathanCape.

Wertheim, A. (2000). The Dramatic Artof Athol Fugard. UK: Indiana University Press.

William, R. (1968). Drama in Performance. Great Britain: Alden and Mow.

Wilson, N.S. (1937). European Drama. Great Britain: C. Trinling\&Co. 